\title{
Brown, Equal Protection, and the Isolation of the Poor
}

\author{
William L. Taylor $†$
}

\section{INTRODUCTION}

The Supreme Court's 1954 decision in Brown v. Board of Education, ${ }^{1}$ striking down state laws that sanctioned racial segregation of public schools, marked the dawning of the modern civil rights era. All of the cases, laws and policies mandating equal treatment and opportunity that followed are traceable in one way or another to Brown; they stand in stark contrast to the policies of governmentally fostered or tolerated racial separation and inequality that preceded.

A full generation has passed since Brown; black and white children born in 1954 are now adults, many with children of their own. Sufficient time has elapsed to permit us to examine retrospectively the effectiveness of Brown, the current vitality of its principles, and its continuing relevance to people whose lives seem far removed from the revolution in civil rights that Brown ignited.

Any fair assessment yields a mass of contradictions. For some who were meant to be the beneficiaries of the new civil rights policies, there has been increased affluence, while for others there has been deepened misery. For the country as a whole, there have been major changes in behavior and attitudes accompanied by persistent prejudice. The story has been one of both striking success and abject failure. In some ways, the children of the 1980's are growing up in a society not very different from the one their parents confronted three decades ago. Racial isolation, division and tension persist. A wide gulf still separates the life opportunities of most black and white children, and there still exists little consensus as to the measures appropriate or effective for dealing with the legacy of discrimination.

$\dagger$ B.A. Brooklyn College, LL.B. Yale Law School. The author, a Washington, D.C. attorney who specializes in civil rights, previously served as a staff attorney for the NAACP Legal Defense Fund and as General Counsel and Staff Director of the U.S. Commission on Civil Rights.

1. 347 U.S. 483 (1954). 


\section{A. Brown and the Caste System}

Despite the continued existence of racial inequality, a fundamental difference between the 1950's and the 1980's should not be obscured: The official caste system that held sway for more than two centuries prior to Brown has been eliminated. Under that system, black people were treated as an inferior class, experiencing daily indignities solely because of their race. Blacks were segregated in all public institutions, provided inferior public services of all sorts, and widely denied the right to vote. They were relegated to the back of the bus, refused food and lodging at restaurants and hotels almost everywhere, addressed by their first names in government offices and court proceedings, denied common courtesies, and threatened with physical and economic repercussions if they stepped out of line. While this system of subjugation was legalized and all-encompassing primarily in the Southern states, much of it existed at least unofficially in the North and West as well.

Today that official caste system is gone. Black people who have the economic means can, for the most part, move with confidence in everyday society-in restaurants, hotels, theatres, public beaches and tennis courts. And, whatever their socio-economic status, blacks can generally expect civil and even-handed treatment at the polls, at the courthouse, on buses and at other public facilities. They command the respect denied to them in the past because they have demanded and won it through their battles fought in the courtroom and the streets.

In important measure these changes in the public face of America reflect the political power achieved by black people. The Brown decision rekindled their hopes and gave new energy to the organizations that represent them. When our national leaders did not enforce Brown, hope and anger combined to fuel the direct action protest movement led by Dr. Martin Luther King, Jr. That movement became the catalyst for the breakthroughs of the 1960 's, including a law that finally provided an effective means for ending racial disenfranchisement. With the passage of the Voting Rights Act of 1965, the energies of the protest movement turned to the political organization necessary to take full advantage of the remedies the law provided.

So, in Birmingham, where Commissioner Bull Connor once set hoses and police dogs on Dr. King and his adherents, a black mayor now presides. In the state capitol, a governor whose "segregation forever" speeches once provided the model for racist politicians now clings to power by making promises to blacks. In Washington, Senators Strom Thurmond (RSouth Carolina) and John Stennis (D-Mississippi), once champions of the old order, cast reluctant votes in 1982 for an extension and strengthening of the Voting Rights Act, a silent tribute to the effectiveness of the 1965 
law in compelling attention to the needs of black constituents. The change in the public face of the nation also stems in part from a recognition of the foothold that black people collectively have gained in the economy. Black faces in television commercials and in front offices of major companies testify to the business creed that no segment of the market place should be neglected.

Yet the explanation for the disappearance of outward manifestations of the old caste system goes beyond the pull of political and economic selfinterest. Experience has proven President Eisenhower wrong in his Sumnerian view that law (specifically the Brown decision) would not change the "hearts and minds" of men. ${ }^{2}$ Law, once it was enforced, did change behavior patterns and eventually the attitudes that underlay them. This change is evidenced by the strategies employed by the Reagan Administration, which, in its attempts to undo many of the remedies for discrimination that have been forged over the past two decades, does not make its appeal using the old code words. Instead, it seeks to persuade the public that it desires to be fair to all and that its policies are consistent with the quest for a "color blind" society of such heroes of the civil rights movement as King, Roy Wilkins, and Thurgood Marshall. More important, the strong resistance that the Administration has encountered to its proposals, from, for example, school boards solicited to join in efforts to end busing for desegregation and employers encouraged to abandon affirmative action, suggests the durability of the institutional and attitudinal changes that have occurred since Brown. Whether or not people are ready to extend the gains made in racial justice, there is little evidence of a nostalgia for the "good old days" of enforced segregation.

These differences in the race relations of the 1950's and 1980's might not have required such lengthy explication were it not for the lack of historical perspective that seems to be an American trait and the current conventional wisdom that governmental efforts to solve social problems are doomed to failure. There is a tendency, particularly on the part of people under the age of thirty-five, to view the pre-Brown regime of "separate but equal" as a foible, easily dispensed with once people focused on its irrationality. Few recognize how deeply entrenched were the roots of the system, not just in economic but in emotional terms, and at what cost in blood and effort the elimination of the old order was purchased. A deeper historical perspective, by demonstrating how far-reaching were the effects of this caste system and what eradicating still existing effects would require, might make people more pessimistic about the possibility of elimi-

2. Eisenhower said in 1958 that "laws themselves will never solve problems that have their roots in the human heart and in human emotions." Quoted in R. SarratT, The Ordeal of SegregaTION 51 (1966). 
nating racism. Yet it might also encourage the belief that even seemingly intractable problems can yield to citizen action through government.

\section{B. Brown and Equal Opportunity}

There was more to Brown than just removing the stain of white supremacy from the nation's lawbooks and its public dealings. Undergirding the decision lay a belief that government has an affirmative obligation to remove barriers that deprive citizens of an equal opportunity to succeed. The Court wrote:

Today, education is perhaps the most important function of state and local governments. . . . It is required in the performance of our most basic public responsibilities, even service in the armed forces. It is the very foundation of good citizenship. Today it is a principal instrument in awakening the child to cultural values, in preparing him for later professional training, and in helping him to adjust normally to his environment. In these days, it is doubtful that any child may reasonably be expected to succeed in life if he is denied the opportunity of an education. Such an opportunity, where the state has undertaken to provide it, is a right which must be made available to all on equal terms. ${ }^{3}$

An opportunity "to succeed in life." Not a guarantee of success, but not merely a formalistic concession either. Rather, a genuine chance to develop one's skills and to reap the rewards of using those skills. Just below the surface of the Brown decision was the belief that segregation laws were not only devices for isolating and humiliating black people, but also shackles that restrained them from moving as far as their abilities would carry them.

If, in the words of Charles Black, segregation was a "massive intentional disadvantaging of the Negro race"4 by state law, then it is not unreasonable to ask three decades after Brown whether the disadvantage has been eliminated or substantially reduced. To the extent that the economic and education gap between blacks and whites has narrowed, one may inquire, within the limits of imperfect knowledge, whether the Brown decision and the laws and policies that followed contributed significantly to black progress. To the extent that the conditions of some black people have not improved or even have worsened, it is legitimate to ask whether the Justices in Brown were wrong in concluding that segregation inhibited black children from acquiring knowledge and skills that would enable

3. 347 U.S. at 493.

4. Black, The Lawfulness of the Segregation Decisions, 69 YALE L.J. 421, 421 (1960). 
them to succeed in life. Alternatively, continuing conditions of deprivation for black people may be accounted for by a failure to break down racial segregation through enforcement of the Constitution and civil rights laws. Or it may be that although the elimination of racial isolation is an important avenue or even a necessary condition to educational and economic advancement, it is not a sufficient condition. Other measures of a public or private character may be needed to establish genuine opportunity.

All of these matters are subject to heated controversy among social scientists who debate the diverse policy prescriptions of contending political ideologies and the nexus between laws and policies and particular outcomes. It is not my intent in this essay to enter into a full scale examination of the relationship between rights, laws and policies and current socioeconomic conditions, but rather to identify a few links that seem reasonably well established.

Such an inquiry may provide useful background material in reviewing: (1) the soundness of remedial principles that have been employed by the courts since Brown and their continuing efficacy in providing opportunities for low-income black people and (2) the applicability of equal protection principles to people whose isolation today may stem as much from their condition of poverty as from their race.

\section{Economic and Social Change Since Brown}

\section{A. Black Gains: 1954-1984}

By familiar and accepted gauges, a significant segment of the black population, particularly people who have come to maturity in the postBrown era, has made striking progress. One key measure of this progress is the movement of black workers from menial and low-paying jobs into more skilled and remunerative occupations. From 1961 to 1982, the proportion of black people in the labor force in professional and technical jobs increased from 4.6 percent to almost 10 percent. ${ }^{5}$ In executive, managerial and administrative jobs, the rise was from 2.5 percent to more than 5 percent. $^{6}$ Although these changes reflect in part a general upgrading of the occupational status of the labor force, gains for white workers during

5. The current figures appear in Center for the Study of Social. Policy, a Dream DefFrRed: The Economic Status of Black Americans 22 (1983) thereinafter cited as Dream Deferrfid, and in Bureau of the Census, America's Black Population, 1970-82, at 11 (1983). Although both are based on census data there are some slight variations in the figures in the two reports. The statistics for earlier years are reported in Malveaux, Shifts in the Employment and Occupational Status of Black Americans in a Period of Affirmative Action, in WorkING PaPERs: BAKKe, WEBer AND AffiRmative ACtion, table 5, at 148 (1979) (hereinafter cited as Working PAPERS].

6. Malveaux, in Working Papers, supra note 5, table 5, at 148. 
the same period were significantly more modest. ${ }^{7}$ When attention is directed to the younger minority groups in the population, even more encouraging indications of mobility emerge. As recently as 1968 , only 12.4 percent of all black women in the 25-34 age category were employed in professional jobs. By 1977, the proportion for the same group (by then the 35-44 age category) had increased to 18.8 percent. $^{8}$

The movement of black people into the professions and other high status occupations is reflected in substantial income gains. In 1981, almost one quarter of all black families had incomes of more than $\$ 25,000$, compared to only 8.7 percent in 1960 (measuring income in constant dollars). ${ }^{9}$ Although the income gap between blacks and whites for the entire population has not narrowed over the past two decades, for those subgroups who have gained some occupational mobility it has closed appreciably. Thus, when considering families where there are two wage earners, black income as a percentage of white income rose from 73 percent in 1968 to 84 percent in $1981 .^{10}$ For younger and more educated blacks, the income gap has closed even more significantly. In 1976 blacks in the 25-29 age group who were college graduates earned 93 percent as much as their white counterparts, a gain of about 12 percent in 7 years. ${ }^{11}$

The improved occupational status and growing income of a segment of the black population reflect important changes in educational attainment. As recently as 1966, the number of black students attending college was only 340,000 . By 1974 , black enrollment had risen to 814,000 , and by 1982 it had reached more than one million. ${ }^{12}$ By 1980,80 percent of black students attended predominantly white institutions, a dramatic shift from the rigidly segregated character of higher education in the past. Changes in expectations and prospects for minorities are suggested by the rise in the proportion of black students majoring in business from 5 percent in 1966 to 18 percent, while concentration in occupations traditionally reserved for blacks declined. ${ }^{13}$

Significant change has also occurred in the enrollment of blacks in professional schools, particularly in medical and law schools. Law school en-

7. Comparing the Malveaux statistics, id., to the Bureau of the Census, Current Population Reports for May, 1982, the figures for whites went from 12.3 percent to 17.3 percent over a 20 year period in the professions and from 11.6 percent to 12.2 percent in managerial and administrative jobs.

8. Malveaux, in Working PAPERS, supra note 5, at 153. For black women in the 25-34 age category in 1977 , the proportion was 18.6 percent.

9. DREAM DEFERRED, supra note 5, at 6.

10. Id. at 8.

11. Wilson, The Declining Significance of Race: Myth or Reality?, in THE Decuining Significanci: of Raci?: A Dialogue Among Black and White Social Scientists 6-7 (Washington ed. 1979).

12. Id. at 8 .

13. Id. at 7. The proportion of black education majors dropped from 45 to 26 percent in the same period. 
rollment rose from 3 percent in 1969 to 4.2 percent in 1979 and 4.7 percent in $1982 .{ }^{14}$ Medical schools, many of which excluded black students until after World War II, had only a 2.6 percent black enrollment in 1969. By 1977, black enrollment had risen to 6 percent. ${ }^{15}$ The magnitude of the change is illustrated by the fact that 3,000 black students were enrolled in medical schools in 1974 at a time when there were only 6,000 black physicians in the nation.

Studies show that significant numbers of advanced black students come from families of lower income and job status. ${ }^{16}$ This indicates that large enrollments reflect increased mobility, not simply changing occupational preferences among middle class families. The striking gains in higher and professional education are evidence that improvements in the economic and occupational status of blacks are products of their own efforts to acquire education and skills and to break down discrimination barriers, not of preferential treatment by government. Further refutation of claims that advances are not based on merit may be found in the improved performance of black students on tests that are widely used as measures of educational ability. At a time of general concern about stagnation and decline in achievement of public school students, the National Assessment of Educational Progress reported gains in cognitive skills by black students. Between 1970 and 1980, the greatest gains in reading skills among nineyear-old children, black or white, were made by black students, students who live in the Southeast, and students who attend school in either rural communities or disadvantaged urban communities. ${ }^{17}$ Although maintaining educational progress through high school has often proved difficult, the generation of black students who came through school in the 1970's

14. Statistics are drawn from figures cited by the U.S. Commission on Civil Rights in Toward Equal Opportunity: Affirmative Admissions Programs at Law and Medical Schools 73-75 (June 1978) and in Statement of Affirmative Action 10-11 (1977), and from the Department of Education's Higher Education General Information Survey. The 1982 data were supplied by the Office for Civil Rights of the U.S. Department of Education to the Center for National Policy Review. Since law school enrollment burgeoned during the 1970's, the numerical increase in minority students is even more noteworthy. In 1969 there were only 2,128 black students enrolled in approved law schools. By 1979 there were 5,257 blacks. See also AMERICAN BAR Association, A Review of Legal. EducaTION IN THE. UNITED STATES 60, 63 (1979).

15. See 51 Journal of Mrdical. Education 1042 (1980); N.Y. Times, Nov. 9, 1980, at 67, col. 5 .

16. See Alexis, The Effect of Admission Procedures on Minority Enrollment in Graduate and Professional Schools, in Working PaPers, supra note 5, at 52, 59-60. Alexis reports that of the class that entered medical school in 1976-77, nearly half of the black students came from families whose incomes were less than $\$ 10,000$. Only 11.6 percent of the white students fell into this category. More than twice as many white students as black students had fathers who had completed college.

17. Nattonal. Assfessmentr of Educational. Progress, Three National assessments of Progrfass in Reading Performance, 197001980 (Rep. No. 11-R-01, Apr. 1981). In addition, the only significant overall gain among the reporting group of 13 -year-olds occurred for black students. Id. at xiii. 
also has managed to narrow the black-white gap on college entrance examinations. ${ }^{18}$

Those blacks who have broken through in the past two decades to better education, more skilled jobs, and higher pay have been rewarded with middle-class status. They are far more likely than blacks in the past to own their own homes, be part of families that never suffer the tragedy of infant death, ${ }^{19}$ and live long enough to become senior citizens. ${ }^{20}$ In sum, for a substantial segment of the black population, the post-Brown era has meant more than the elimination of official racism-it has brought genuine opportunity. The status of some may not be secure and there are often galling reminders of prejudice, but many blacks have joined the mainstream. Although the ranks of the black middle class remain small compared to whites, the story of the past two decades is one of individual and collective progress exceeding that made by blacks in any other period in American history.

\section{B. Failure: 1954-1984}

If the past three decades have brought genuine access to opportunity for many black people, even more find their situation unchanged or even worsened. The statistical evidence for this conclusion is by now depressingly familiar. For almost all of the period from 1954 to 1984, in good economic times and bad, the unemployment rate for blacks has been approximately double that for whites. During 1983, when white unemployment reached 10 percent, black unemployment was more than 20 percent, the highest point it had reached in the three decades since Brown. In part, this worsening situation reflects the failure of the economy and of national policy to produce jobs for a growing black population. During the period from 1960 to 1982, the black male population over the age of 16 almost doubled from 5.6 million to 10.73 million. ${ }^{21}$ But the number of employed black men increased only from 4.15 million to 5.94 million, adding 3.4 million black men to the ranks of the unemployed. ${ }^{22}$ As a result, the pro-

18. Wash. Post, Aug. 31, 1983, at A6, col. 2.

19. Black infant deaths, which numbered 44.3 for every thousand live births in 1960 , decreased to 21.8 per thousand in 1979. White infant deaths were 11.4 per thousand in 1979. Dream Deferred, supra note 5 , at 47.

20. The life expectancy of black males at birth was 65.5 years in 1979 , an increase of more than four years since 1960, and 74.2 ycars for black females, an increase of almost eight years since 1960 . Life expectancy for white males and females in 1979 was more than four years longer than their black counterparts. Id. at 48.

21. Drfam Defrered, supra note 5, at 20. Despite the fact that the unemployment rate for black teenagers is often more than 50 percent, they accounted for only a small portion of the 3.4 million unemployed black males.

22. Id. 
portion of black males over the age of 16 who were employed dropped from 74 percent in 1960 to 55 percent in $1982 .{ }^{23}$

One major consequence of the crisis in black unemployment is the persistence of a wide gap between black and white family incomes. In 1981 the median income of black families was 56 percent of that of white families, scarcely improved from the 55 percent ratio that existed in $1960 .{ }^{24}$ Real income for black families rose during that time from a median of $\$ 9,919$ to $\$ 13,266$, but, as indicated above, the gains were reaped largely by some subgroups (e.g., younger, two-income families) while others, both working and unemployed, were left mired in poverty.

The human impact of joblessness and low income may be assessed in various ways, but one important gauge is its impact on children. In 1959, two of every three black children under the age of 18 were growing up in poverty. In 1981, 45 percent of all black children under the age of 18 still were living in poverty; ${ }^{25}$ in 1985 the figure had risen to 48 percent. ${ }^{26}$ Although the change from the 1950's indicates some progress, the fact that in the 1980's almost half of all black children, compared to 14.7 percent of white children, ${ }^{27}$ grow up in impoverished circumstances is striking commentary on the status of the quest for access to opportunity.

Moreover, in recent years changes in the characteristics of poverty place additional barriers in the way of poor black children. In the 1950's and 60 's, although many black children were born into poverty, they were usually raised in households where both parents were present. By 1981, 47 percent of all the black families in the nation were headed by women who were responsible for raising children without the presence of a spouse. $^{28} \mathrm{~A}$ very high proportion of these families were poor. Indeed, in female-headed black families two of every three children under the age of 18 and three of every four under the age of six live below the poverty level. ${ }^{29}$ All told, about three million of the nine million black children in the nation are growing up in impoverished, single-parent households, with mothers who are responsible for raising them and bringing income into the home. ${ }^{30}$

23. N. Y. Times, July 18,1983 , at $\Lambda 8$, col. 1 .

24. DRFAM DrFerRrd, supra note 5 , at 4 . In contrast, a recent study by the Rand Corporation indicates that among working men, the ratio of black male wages to white male wages reached $72.6 \%$ in 1980. N.Y. Times, Mar. 2, 1986, at E8, col. 1.

25. Dream Defrerkd, supra note 5, at 25-27.

26. N.Y. Times, Oct. 20 , 1985 , at 1 , col. 1 .

27. Dream Defrerked, supra note 5 , at 25.

28. Id. at 29 . By 1985 , the figure reportedly had reached 50 percent. Wash. Post, Jan. 20, 1986, at $\mathrm{Al}$, col. 1.

29. Dream DrFkrRed, supra note 5 , at 26.

30. Id. Although the breakup of families is a phenomenon that affects all races, it is striking that only three million of the more than $\mathbf{5 0}$ million white children in the country live in female-headed households that are poor. Id. 
In addition, large numbers of poor black children are tightly concentrated in the poverty areas of central cities. ${ }^{31}$ While black families who have acquired middle-class status have gained some residential mobility, the poor have not. In the ghetto areas of major cities, black children living in poverty increasingly are isolated from other children in their schools and neighborhoods by income as well as race. The risk is great that they will be afflicted with nutritional and health problems, that they will suffer parental neglect or abuse, that they will become involved with drugs, that they will leave school without acquiring basic skills, and that they will become victims or perpetrators of crime. Some, by dint of extraordinary talent or effort or with the help of a caring adult, will surmount their environment, but the odds against them are very high. ${ }^{32}$

\section{The Link Between Givil Rights Law and Social Change}

Controversy inevitably surrounds any discussion of both the causes of the progress described above and the reasons why the conditions of some people have stagnated or worsened. The advances made by black people have come through a complex process not easily attributable to any single set of laws or court decisions. Victories in court were a kind of selfempowerment for black people that led to other successful legal, political and community efforts. From these successes followed heightened aspirations and increased confidence, confidence that was reinforced when people discovered they had the inner resources to withstand attacks on their rights. None of this is easily susceptible to calibration by social scientists.

Nevertheless, it is possible to gauge the impact of certain remedy decisions of the courts and related governmental civil rights policies on minority progress. Chief among these measures are court decisions and government actions to reduce racial isolation in the public schools and affirmative action decisions and policies aimed at increasing minority participation in employment and higher education.

\section{A. School Desegregation}

Although the Brown decision is more than three decades old, massive resistance by government officials in the South prevented effective enforce-

31. Id.

32. Social scientists seek to distinguish between people who are temporarily poor and those who are poor over the long term. While under current standards more than 30 million Americans are classified as "poor," research indicates that for as many as two-thirds of them poverty is a temporary condition. Among the characteristics associated with long-term poverty is membership in a femaleheaded household. While a majority of the overall poor population is white, it is estimated that the long-term poor (sometimes used synonymously with the term "underclass") are predominantly nonwhite. See K. AUl.etra, The. UNDERCLASS 27-30 (1983). 
ment for almost the entire first half of that period. It was only after Congress endorsed the decision in the 1960's and the Executive branch indicated a readiness to enforce it through lawsuits and the withholding of funds from noncomplying school districts that the Supreme Court finally spelled out the remedial obligations of public school systems that had engaged in deliberate segregation. So it was not until 1971 that the Court determined that pervasive mandatory segregation practices could be redressed only by comprehensive mandatory desegregation, including, if necessary, the use of busing. ${ }^{33}$ And it was not until 1973 that the Court first confronted the problem of segregation in the North and West, holding that similar comprehensive remedies were called for where evidence showed that segregative practices, though not official or blatant, were nonetheless deliberate and pervasive. ${ }^{34}$ Accordingly, many of the school districts that have undergone desegregation have done so only in the past 15 years. Even in this short time, the remedy has brought positive results.

As noted, in the 1970's the most striking gains on standardized reading tests were registered by black elementary students in the Southeast, where sweeping changes were being made to implement desegregation. ${ }^{35}$ This strong hint of a link between desegregation and academic achievement is reinforced by case studies of particular communities that have undergone desegregation. The studies show that in most situations where courts have ordered desegregation through busing, the achievement levels of minority students have risen significantly while those of white students remained unchanged or have even risen slightly. ${ }^{36}$

Interestingly, black children achieve the most dramatic gains when participating in metropolitan or county-wide plans that often entail substantial busing. ${ }^{37}$ These are plans which ordinarily achieve substantial desegregation across socioeconomic class as well as race lines. The findings are consistent with research showing that disadvantaged children fare better in schools and classrooms which are made up largely of advantaged students rather than being isolated with others of the same background. ${ }^{\mathbf{3 8}}$

33. Swann v. Charlotte-Mecklenburg School Bd., 402 U.S. 1 (1971).

34. Keyes v. School Dist. No. 1, Denver, Colorado, 413 U.S. 189 (1973).

35. See supra note 17.

36. R. Crain \& R. Mahard, Disfgregation Plans That Raise Black achievement: A Rrvikw of THE RrSkARCH 35-45 (1982) (desegregation raises achievement and I.Q. test scores for blacks). The studies also show that certain other factors influence the strength of the academic gains. The best progress appears to have occurred where desegregation began in kindergarten or first grade, and where comprehensive programs were instituted that included diagnostic and compensatory services for students and in-service training for teachers.

37. Id.

38. See, e.g., Office: of Educ., Dep't of Health, Educ., \& Welfare, Equality of EnucaTional. OpPoRtuniry (1966); U.S. COMm'N ON Civil Rights, Racial. Isol.ation in the Public Schools (1967); F. Mosthllier \& D. Moynihan, ON Equality of Educatrional. OpportuNrrY (1972). One explanation is that in schools consisting predominantly of advantaged children, the 
In the longer term, black children attending desegregated schools are more likely to complete high school, to enroll in and graduate from fouryear desegregated colleges, and to major in subjects nontraditional for minority students-majors that lead to more remunerative jobs and professions. ${ }^{39}$ In addition, low-income black children who receive a desegregated education have a good chance to avoid the social pathology (such as hostile encounters with the police or teenage pregnancy) that blights the prospects of many of their peers. ${ }^{40}$

Finally, school desegregation has helped to ease traditional patterns of rigid residential segregation. ${ }^{11}$ This added benefit results, in part, from the process of desegregation itself. Once the racial character of a neighborhood can no longer easily be stamped by an identification of its schools as black or white, racial barriers in housing begin to lower. In addition, longitudinal studies of black and white students who are assigned to desegregated schools suggest that when they become adults they are more likely than their racially isolated peers to choose to live in racially integrated neighborhoods. ${ }^{42}$

The explanations for these positive outcomes of school desegregation are varied. Some emphasize the ability of schools dominated by white middleclass parents to command resources (such as good teachers and good libraries) that ordinarily are beyond the reach of low-income minority parents. Others stress the positive impact on low-income children of peer pressures and middle-class norms or the practical know-how and contacts these youngsters acquire once they enter middle class society. ${ }^{43}$ Controversy persists, too, about the strength and duration of the positive outcomes linked with school desegregation and whether, as a matter of policy, the investments of energy and resources might better have been placed in

norms set by the parents and teachers, and by students themselves, ordinarily are high. Academic success and advancement to college are expected or demanded. Where schools fall short, middle-class parents are practiced in wielding influence to bring about change.

39. McPartland, Desegregation and Equity in Higher Education and Employment: Is Progress Related to the Desegregation of Elementary and Secondary Schools?, 42 LAW \& CoNTEMP. PROBS., Summer 1978, at 108, 110-13, 124, 131; McPartland \& Braddock, Going to College and Getting $a$ Good Job: The Impact of Desegregation, in EFfective SchOOL Desegregation 141, 146, 150 (W. Hawley ed. 1981).

40. These findings emerge from a long term study of some 700 low-income students in Hartford, Connecticut, one group of which began desegregation in the 1960's, while the other remained in segregated schools. See N.Y. Times, Sept. 7, 1985, at C2, col. 2; see also R. CRAin \& J. STrauss, Scihool. Dishigricintion and Black Educational AtTainments (Center for Social Organization of Schools, The Johns Hopkins Univ., Rep. No. 359, July 1985).

41. D. Pyarce, Brfaking Down Barriers: New Evidence on the Impact of Metropolitan School. Desegregation on Housing Patterns (1980).

42. Id.

43. D.W. Brogan, a perceptive observer of the American scene, once pointed out that schools were places where students "instruct each other in how to live in America," noting the lessons in "practical politics, in organization, in social ease" that are part of the informal curriculum of high schools. D. Brocian, Thr: American Character 170, 174-75 (1956). 
other types of educational reform. ${ }^{44}$ No serious student of the issue, however, has disputed the basic proposition of Brown that state-imposed racial isolation causes harm and that desegregation may bring about educational opportunity.

\section{B. Fair Employment and Affirmative Action}

In contrast to public education, the principal vehicle for combatting racially discriminatory practices in employment has not been direct judicial construction of the Fourteenth Amendment, but enforcement and court interpretation of a statute, Title VII of the Civil Rights Act of $1964 .{ }^{45}$ As a matter of statutory interpretation, in 1971, the Supreme Court determined in Griggs v. Duke Power Company that practices that operated to deny opportunities to minorities were in some cases prohibited by Title VII even when they were not intentionally discriminatory. ${ }^{46}$ This has meant that employers seeking to screen applicants through the use of intelligence examinations or other tests disproportionately excluding minorities must demonstrate that the tests are job related or adopt other screening techniques that do not disadvantage minority applicants. The broader approach taken by Congress has enabled enforcement authorities to deal with practices that disadvantage minorities even where such practices are not facially discriminatory or racially motivated, standards that would have to be met if the basis for challenge was a denial of equal protection. ${ }^{47}$

Major breakthroughs have also occurred at the remedy stage of employment discrimination cases. Where courts have found the existence of pervasive patterns or practices of discrimination, they have ordered strong affirmative remedies, sometimes restraining employers from hiring new white employees until proportionate numbers of qualified minority employees are hired. ${ }^{48}$ Those Title VII remedy decisions, along with similar policies pursued by the executive branch in articulating the equal opportunity obligations of government contractors, ${ }^{49}$ have been the subject of

44. Compare Bell, Serving Two Masters: Integration Ideals and Client Interests in School Desegregation Litigation, 85 YAl.: L.J. 470 (1976) with Jones, Correspondence, 86 YALE L.J. 378 (1976).

45. 42 U.S.C. $\$ \$ 2000$ e to $2000 \mathrm{e}-17$ (1982).

46. 401 U.S. 424,432 (1971).

47. See Washington v. Davis, 426 U.S. 229, 239-41 (1976).

48. See, e.g., Setser v. Novack Inv. Co., 638 F.2d 1137 (8th Cir.), cert. denied, 454 U.S. 1064 (1981); United States v. Lee Way Motor Freight, Inc., 625 F.2d 918 (10th Cir. 1979); United States v. City of Chicago, 549 F.2d 415 (7th Cir. 1977); Boston Chapter, NAACP v. Beecher, 504 F.2d 1017 (1st Cir. 1974), cert. denied, 421 U.S. 910 (1975); Rios v. Enterprise Ass'n Steamfitters Local 638, 501 F.2d 622 (2d Cir. 1974); United States v. Masonry Contractors Ass'n, 497 F.2d 871 (6th Cir. 1974); NAACP v. Allen, 493 F.2d 614 (5th Cir. 1974); United States v. Ironworkers Local 86, 443 F.2d 544 ( 9 h Cir.), cert. denied, 404 U.S. 984 (1971); Contractors Ass'n v. Secretary of Labor, 442 F.2d 159 (3rd Cir.), cert. denied, 404 U.S. 854 (1971).

49. President Johnson's Executive Order 11246, adopted in 1965, requires government contrac- 
great controversy as matters of law and policy. But there is little question that such affirmative action remedies have provided minorities with access to job opportunities and advancement.

Studies of the huge Bell Telephone system conducted after the company entered into a Title VII consent decree in 1973 calling for the use of numerical goals and timetables showed that black workers had made substantial gains in entering managerial and skilled craft positions. ${ }^{50}$ Similar progress was reported in the employment of minorities in skilled positions in the steel industry following a Title VII consent decree in $1974 .^{\text {s1 }} \mathrm{In}$ law enforcement, which during the late 1960's and 1970's was a special target of Title VII litigation and affirmative action remedies, the numbers of black police officers increased from 24,000 in 1970 to 43,500 in $1980 .^{52}$

Parallel policies pursued by the executive branch, notably the requirement that government contractors set specific targets for the employment of minorities, have also produced significant gains. ${ }^{53}$ Goals and timetables requirements first arose out of an investigation of minority employment in the construction trades in Philadelphia in the late 1960's. At that time, fewer than 1 percent of construction workers in the area were minorities. By 1982, as a result of affirmative action requirements, more than 12 percent of Philadelphia's construction workers were minorities, a dramatic increase (although short of the established goal of 19 to 26 percent). ${ }^{54}$ Broader studies of the contract compliance programs have indicated that companies subject to goals and timetables requirements had greater success during the 1970's in increasing minority employment in a variety of job categories than did companies not subject to such requirements. ${ }^{55}$

Although one criticism of affirmative action remedies has been that they

tors to take affirmative action in hiring and promoting minorities.

50. See Oversight Hearings on Equal Employment Opportunity Part 1: Hearings Before the Subcomm. on Employment Opportunities of the House Comm. on Educ. and Labor, 97th Cong., 1st Sess. 219, 221 (1981) (statement of economist Bernard Anderson).

51. Id. at 528-29 (statement of economist Phyllis Wallace).

52. See Sawyer, Affirmative Action: Birth and Life of a "Bugaboo," Wash. Post, April 11, 1982, at $A 10$, col. 5 . Among the many cases in which courts ordered numerically based relief to correct patterns of discrimination in state or local law enforcement agencies were Boston Chapter, NAACP v. Beecher, 504 F.2d 1017 (1st Cir. 1974), cert. denied, 421 U.S. 910 (1975); NAACP v. Allen, 493 F.2d 614 (5th Cir. 1974); United States v. City of Chicago, 549 F.2d 415 (7th Cir. 1977); and Morrow v. Crisler, 491 F.2d 1053 (5th Cir.) (en banc), cert. denied, 419 U.S. 895 (1974).

53. The goals and timetables requirements were adopted in 1970 and 1971 as regulations to implement E.O. 11246 promulgated by President Johnson in 1965, and are codified at 41 C.F.R. $\S \S$ 60-2.1 to 60-2.4 (1985).

54. Sawyer, supra note 52 , at $\Lambda 10$, col. 5 .

55. See J. Lionard, The Impact of Affirmative Action (1983); Office of Federal Con'tracil Complianc: Programs, Employment Standards Administration, U.S. Dep'T of LaBor, $\Lambda$ REvitw of the Effecis of Executive Order 11246 and the Federal. Contract Complianc:F Progiram on Employment Opportunities of Minorities and Women (1983). Both

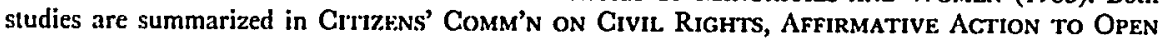
THF: DoORS OF JOB OPPOR'UUNTY 122-26 (1984). 
tend to benefit minorities who are already advantaged or middle class, the results summarized above suggest otherwise. The focus of much of the effort has been not just on white collar jobs, but also on law enforcement, construction work, and craft and production jobs in large companies-all areas in which the extension of new opportunities has provided upward mobility for less advantaged minority workers. Nor does the criticism appear valid for the professions. Studies show that of the increased enrollment of minority students in medical schools during the 1970's, significant numbers were from families of low income and job status, indicating that the rising enrollment of minorities in professional schools stemming from affirmative action policies reflects increased mobility, not simply changing occupational preferences among middle class minority families. ${ }^{\text {sB }}$

\section{Reasons for Failure}

If the links between particular civil rights policies and the gains made in education and employment are not free from dispute, the causes of the continuing (and in some cases widening) gaps between blacks and whites are subject to far greater controversy. Conservatives argue that unemployment, income and poverty data for blacks indicate that civil rights policies and Great Society social welfare programs have proved ineffective. Liberals respond that civil rights remedies have been effective to the extent that they have been implemented and should be viewed as a necessary but not a sufficient condition for the advancement of lower income blacks. Affirmative action, they say, cannot bring true employment opportunity for poor people without basic skills preparation and job training; fair housing laws are not helpful to people who do not have the resources or government assistance to acquire decent shelter. Liberals point to evidence of the positive impact of some (though by no means all) of the Great Society programs that were designed to provide educational or job mobility. Headstart and other preschool programs, by beginning the teaching process early and providing basic health and nutritional services, have helped poor children start off on a more even footing and have resulted in aptitude gains that many children have maintained as they grow older. ${ }^{87}$ The Job Corps has achieved a measure of success, recognized by both liberals and conservatives, in meeting the job preparation needs of economically disad-

56. See Alexis, supra note 16 , at 52-71; see also supra note 16.

57. See J. OGbu, Minority Education and CaSTe (1978) (summarizing research on early childhood education). A recent long-term study of the effects of carly-childhood education (beginning at age 3) on a group of low-income black children in Michigan provides even more encouraging news. D. Weikart, Changed Lives (1984). 
vantaged teenagers, particularly minorities and others who have dropped out of school with low reading skills and no employment record. ${ }^{88}$

The difficulty, say advocates of these programs, is that the programs have been available to only a small proportion of the people in need of such benefits and services. Similarly, many blacks have yet to reap any practical benefit from civil rights laws and policies against government enforced racial isolation. When the Brown decision was issued in 1954, the movements towards black urbanization and white suburbanization were still incomplete. By the time the Brown principle was applied to cities of the North and West, these movements were far more advanced and many large central city school districts had become predominantly or almost exclusively minority in their racial composition. One potential solution to this problem-treating an entire metropolitan area as a single entity for purposes of school desegregation-was inhibited when the Supreme Court erected stringent proof requirements for cross-district desegregation. $^{5 \theta}$ In short, many black children, born since the Brown decision, have grown up in complete racial isolation. For them, to paraphrase G.K. Chesterton's observation about Christianity, it cannot be said that desegregation has been tried and found wanting but rather that it has been found difficult and not tried.

In the economic sphere, liberals and conservatives largely agree that major changes in unemployment and poverty rates are influenced far more by macroeconomic forces than by policies targeted to anti-discrimination or job training. Few would dispute the proposition that in recent years the prospects for advancement of those who are the least well-off have been dimmed by the slow growth of the American economy, by the shift in the economy away from manufacturing (particularly in areas such as automobiles and steel where production-line jobs traditionally have offered channels of opportunity for those at the bottom of the ladder) and by the development of cheap labor markets abroad. Once the focus shifts from diagnosis to prescription, views vary widely. Some conservatives believe that answers lie in government deregulation and in supply-side economics which, they assert, will ultimately improve the economic conditions of everyone, including the poor. Some liberals argue that the remedies must include government initiatives to enlarge the supply of jobs in the public and private sectors and policies that dedicate a larger share of the nation's wealth to meeting public needs.

In the area of welfare, there is also widespread agreement that current government policies are a failure, but much disagreement about the rea-

58. Slobig, Young Americans, Their Deteriorating Status in the Labor Market (unpublished manuscript 1983).

59. See Milliken v. Bradley, 418 U.S. 717 (1974) (Milliken I). 
sons and needed reforms. Conservatives feel strongly that federal welfare assistance, augmented since the 1960 's by other entitlement programs such as food stamps, has created an unhealthy dependency among the poor, robbing them of incentives to seek work and inducing them to become permanent wards of the state. For many of these conservatives, the appropriate response is a major reduction in welfare assistance of various kinds, a step they believe will lead to a greater assumption of responsibility by private institutions such as the church and a renewal of individual initiative.

Liberals believe that, far from rewarding idleness, the benefit levels of welfare programs in most states are so low that they do not meet basic needs. Further, they say that if economic independence is the goal, it can be achieved only by providing an array of services including job training and low-cost day care for the many young mothers on welfare. Liberals also note that if welfare policy is to encourage people to work, payments should continue to be made, albeit in reduced amounts, to people who are able to earn some income through their own labors. When people with such marginal incomes are cut off from benefits on the grounds that they are not "truly needy," dependency may be encouraged, not discouraged. Most liberals call for the establishment of national welfare standards that would raise benefit levels in most states and the provision of government services, such as basic skills and job training and child care, which they believe will foster economic independence.

\section{Summary}

The choices made concerning economic and social welfare issues from among the welter of conflicting diagnoses, assumptions, values and prescriptions will have an important impact on the futures of many people who live in poverty. It is clear, too, that most of the issues must be resolved in the crucible of legislative debate in a democratic society. But the debate about economic and social welfare issues affecting the poor cannot be divorced from continuing judicial questions of equal protection for minorities. In examining those questions, thirty years of experience since Brown have clarified a number of matters. One is that apart from the legal basis for the decision, the Brown Court was on solid ground in finding a link between state imposed segregation and the denial of educational opportunity and in assuming that the removal of racial isolation would create conditions favorable to the advancement of black people. A second is that, whatever the theoretical possibilities may be for the development of opportunity and self-sufficiency in an environment of racial isolation, in practice minorities who are most isolated in society today are also those 
who are worst off. ${ }^{60} A$ third is that many black people, including large numbers born since 1954, have never been offered any affirmative remedy from the conditions of segregation and deprivation imposed by the old caste system.

\section{The Rationale For Race Conscious Remedies}

Equity jurisprudence is dotted with maxims designed to aid judges in fashioning remedies. "The nature of the violation," we are told, "determines the scope of the remedy." The purpose of a remedy, it is said, is to restore the person wronged to the position he would have occupied "but for the commission of the wrong."

Such axioms may indeed furnish useful guidance in cases involving individual victims and perpetrators, discrete violations and easily identifiable consequences of the violations. But how does one match remedy to the scope of a violation consisting of the creation of a state-enforced caste system, where the wrong subjected a whole class of people to conditions of isolation and deprivation for more than three centuries? How can judges not possessed with powers of clairvoyance ascertain the position that members of the wronged class would have occupied but for the shackles imposed by this caste system?

Faced with this dilemma, the federal courts over the past two decades generally have opted for affirmative redress, remedies urged by plaintiffs that would change their practical situation, not merely their formal position in the eyes of the law. ${ }^{61}$ The basic principle guiding the courts has been a belief that the caste system, enforced for so many years, necessarily visited harmful results on members of the disfavored class-results that went beyond the immediate impact of any particular racial practice and that would not be redressed fully by the simple termination of the practice. Further, the Supreme Court decided that proof of unshakable causal

60. It has been pointed out that the departure of blacks who have secured jobs, housing and other opportunities outside racially isolated areas worsens the situation of those who remain by depriving the community of resources and potential leadership. But a policy of preventing "brain drain" by urging blacks to forgo opportunities and remain in racially isolated communities hardly seems feasible.

61. In seeking to link remedy to violation, the Court has followed what some commentators term "the corrective conception" of antidiscrimination law. See Gewirtz, Choice in the Transition: School Desegregation and the Corrective Ideal, 86 CoLum. L. REv. 728, 731-35 (1986). Two other approaches, one extremely narrow and the other extremely broad, avoid the dilemma by denying the relevance of linkage. Under the "prohibitory" approach pursued by the Reagan Administration's Justice Department, the only class relief viewed as appropriate is future-oriented. Defendants may be ordered to cease their discriminatory practices but any additional affirmative redress for the class, even if designed to undo the effects of past discrimination, is regarded as unnecessary and, indeed, as an unacceptable departure from the concept of "color blindness." In contrast, proponents of a "distributive" or results-oriented concept regard integration or fair allocations of goods and services among the races as appropriate remedies once a violation of the Constitution is found whether or not the remedy can be linked to the wrong. Neither approach has found favor in the federal courts. See id. at 735-39 (criticizing prohibitory and distributive approaches). 
links between the violation and the remedy sought would not be a precondition of affording broad, affirmative remedies. Instead, the Court chose to gauge the propriety of particular remedies by taking a common sense view of the likely consequences of particular practices.

The general approach of the judiciary is well illustrated by the Supreme Court's handling of remedy in school desegregation cases. Once the Southern strategy of massive resistance had run its course, school boards had to develop plans for desegregation. Two methods favored by the school boards were "neighborhood" school assignments, under which students would attend schools close to their homes, and "freedom of choice" plans, under which segregated patterns would be altered only through the exercise of parental choice.

In assessing neighborhood school plans, courts came to grips with the fact that to some substantial, if unquantifiable, degree the state-imposed segregation of the public schools had shaped the racial makeup of neighborhoods. ${ }^{62}$ Recognizing that people tend to cluster near the schools their children are permitted to attend and that therefore racially segregated schools contributed to segregated residential patterns, the courts refused to accept ostensibly neutral neighborhood assignments that would perpetuate school segregation as constitutionally adequate redress.

Similarly, the Supreme Court effectively rejected "freedom of choice" as a constitutionally adequate remedy by holding that such plans would be permitted only where school authorities could demonstrate that they would produce integrative results. ${ }^{63}$ Implicit in the Court's decision was an understanding that a caste system that relegated black people to positions of economic dependency and physical vulnerability was hardly conducive to the free exercise of choice. These conditions of dependency and vulnerability persisted even after the formal restraints of segregation laws were lifted, as did fears and prejudices among whites engendered by many years of state-imposed isolation. ${ }^{64}$ Plaintiffs could not have demonstrated that the remedy they sought-schools with a racial composition that roughly reflected the composition of the school system as a

62. Swann v. Charlotte-Mecklenburg Bd. of Educ., 402 U.S. 1, 7, 14, $20-21$ (1971).

63. Green v. County School Bd., 391 U.S. 430 (1968).

64. The Court in Green demonstrated an awareness that these conditions existed. Id. at $440 \mathrm{n} .5$ (quoting United States Commision on Civil Rights, Southern SchoOl. Desegregation 1966-67, at 88 (1967)). But ruling out "freedom of choice" plans only on proof that the choice of black parents was inhibited would have set off a new round of litigation that might have lasted another decade. Thus the Court chose the simple test of whether the plan resulted in actual desegregation. For a fuller discussion of the remedial principles of Green, see Gewirtz, supra note 61. Some have argued that black people, as victims of enforced segregation, should be permitted to opt out of a remedy to which they may be entitled and their choices should not be presumed to be coerced. But the rights of black parents who seek a full remedy for their children cannot be completely vindicated by a plan that permits such exception. The right is not simply to attend a formerly white school but to attend a system from which the taint of racial discrimination in assignment has been removed. 
whole-mirrored the situation that would have existed "but for" the constitutional violation. But acceptance of the remedy proffered by defendant school authorities would have yielded only a formal equality, devoid of practical significance and oblivious to the real consequences of the reign of segregation.

One additional school case illustrates the practical approach the courts have taken. In Milliken II, the Supreme Court, as part of the redress given after a finding of deliberate segregation of the Detroit school system, upheld lower court rulings requiring state and local officials to provide resources for compensatory education programs in reading and mathematics, in-service training of teachers, and guidance and counseling programs. ${ }^{65}$ The Court reasoned as follows:

Children who have been . . . educationally and culturally set apart from the larger community will inevitably acquire habits of speech, conduct, and attitudes reflecting their cultural isolation. They are likely to acquire speech habits, for example, which vary from the environment in which they must ultimately function and compete, if they are to enter and be a part of that community. This is not peculiar to race; in this setting, it can affect any children who, as a group, are isolated by force of law from the mainstream. ... The root condition shown by this record must be treated directly by special training at the hands of teachers prepared for that task. ${ }^{66}$

Again, the link between the violation and the remedy may be viewed by some as less than airtight. ${ }^{67}$ But the Justices chose to take a common sense approach to the issue and to seek correction of problems that clearly inhibited opportunity for black children.

The only major departure from the relatively liberal and pragmatic remedial approach the Court has taken in school desegregation cases was its rejection in Milliken I of an effort to secure an interdistrict school remedy ${ }^{68}$ In that case, the five-member majority acknowledged the commission of constitutional violations by Michigan and Detroit government officials, the responsibility of the state for the drawing of school district lines, and the existence of pronounced segregation as between the predominantly black schools of the Detroit school district and the white schools of suburban districts. But the majority had great difficulty seeing any linkage between the segregative acts and the segregated conditions. Justice Burger simply asserted that segregative acts that "within an autonomous" district

65. Milliken v. Bradley, 433 U.S. 267 (1977) (Milliken II).

66. Id. at 287-88 (citation omitted).

67. Nlthough the Court said that there was "abundant evidence" to support its conclusion and remedy, the record in support consisted principally of the expert opinions of educators. Id. at 273 n.9.

68. 418 U.S. 717 (1974). 
would give rise to a duty to provide relief, or at least to a presumption of wide impact, did not carry the same weight when a school district line was involved. ${ }^{69}$ Nor, despite the powerful teaching of Cooper $v$. Aaron ${ }^{70}$ that a state may not evade its constitutional obligations by compartmentalizing them, was the majority prepared to consider evidence in the record that segregated public schools in the Detroit metropolitan area were the product of racial discrimination in housing on the part of government officials. ${ }^{71}$ Accordingly, although constitutional violations had occurred and although no member of the Milliken majority asserted a clear conviction that racial segregation in the Detroit metropolitan area was adventitious or largely the product of private choice or economic factors, the Court denied an interdistrict remedy. ${ }^{72}$ The Court, however, did leave the door open to interdistrict remedies in other cases on appropriate showings of violations with "interdistrict effects," and it has refused to disturb lower court holdings in subsequent cases that the conditions for metropolitan relief had been satisfied. ${ }^{73}$

The Court's treatment of fair employment issues has been more in line with the pragmatism of Green, Swann and Milliken II. In Griggs, the Court was interpreting legislative history that was far from clear. ${ }^{74} \mathrm{~A}$ narrow view might have focused exclusively on the question of fault, absolving employers and unions who were not acting out of bad motives from the responsibility of making costly changes in their employee selection processes. Further, the Court might have reasoned that whatever the past practices of discrimination that the Duke Power Company may have engaged in, the disproportionate failure rate of minorities on tests used by the company was traceable more to discrimination in public school systems than to the practices of the employer. But the Court was less concerned with attempting the impossible task of allocating responsibility for

69. Id. at $741-42$.

70. 358 U.S. 1 (1958).

71. The majority simply ducked the housing issue with the observation that although the district court had made findings of housing violations, the court of appeals did not consider them because it found the school violations sufficient. 418 U.S. at 728 n.7. This refusal to consider the housing violations was at odds with longstanding Supreme Court practice. See Dandridge v. Williams, 397 U.S. $471,475-76$ n.6 (1970). Justice Stewart, the one member of the majority who considered the housing proof, found it unpersuasive and suggested that the factors producing racial separation in metropolitan areas might be so complex as to be "unknown and perhaps unknowable." 418 U.S. at 756 n.2.

72. One plausible explanation for the Court's departure from previously established principle was the politically explosive character of the case. Justice Marshall said that "[t]oday's holding, I fear, is more a reflection of a perceived public mood that we have gone far enough in enforcing the Constitution than it is the product of neutral principles of law." 418 U.S. at 814. See Taylor, The Supreme Court and Urban Reality: A Tactical Analysis of Milliken v. Bradley, 21 Wayne L. Rev. 751 (1975).

73. See, e.g., Evans v. Buchanan, 555 F.2d 373 (3rd Cir.), cert. denied, 434 U.S. 880 (1977); United States v. Board of School Comm'rs, 637 F.2d 1101 (7th Cir.), cert. denied, 449 U.S. 838 (1980).

74. Griggs v. Duke Power Co., 401 U.S. 424 (1971). 
what may have been multiple wrongs ${ }^{75}$ than with finding workable solutions. As it said in a later case:

Griggs was rightly concerned that childhood deficiencies in the education and background of minority citizens, resulting from forces beyond their control, not be allowed to work a cumulative and invidious burden on such citizens for the remainder of their lives. ${ }^{76}$

In dealing with explicit racial goals or set-asides, the Court has suggested that the standard is one of practical necessity - whether lesser measures would suffice to overcome the institutional inertia that works to exclude minorities from job opportunities even after formal practices of discrimination have been terminated. ${ }^{77}$

In employment, the tests of practicality and of balancing competing interests work two ways. A black person apparently may be denied a job he would have held "but for" the discriminatory practices of an employer if awarding the position would require the displacement of an incumbent white person. ${ }^{78}$ In determining whether race-conscious remedies "unnecessarily trammel the interests of the white employees,"79 courts may draw lines between actions that disappoint the expectations of whites and those that uproot them from vested status. If the Court perceives such linedrawing as being generally fair, it may reject the argument that in a particular instance one or another individual may suffer hardship. ${ }^{80}$ In short,

75. In Griggs, the decision was based in part on the fact that the Duke Power Company had in the past intentionally excluded minority applicants from its workforce. To permit exclusionary practices to be replaced by a "neutral" test that adversely affected minorities would have perpetuated past discrimination. But a new employer with no history of past discrimination is also subject to the Griggs rule against tests that adversely affect minority applicants unless justified by business necessity.

76. McDonnell Douglas v. Green, 411 U.S. 792, 806 (1973).

77. See, e.g., Fullilove v. Klutznick, 448 U.S. 448, 462-63 (1980) (opinion of Burger, C.J.). Lower courts have justified the use of a hiring ratio in similar terms, such as where it is determined that it "represents the only rational, non-arbitrary means of eradicating past evils." NAACP v. Allen, 493 F.2d 614, 619 (5th Cir. 1974).

78. Nlthough the Stotts case did not deal explicitly with the situation described, Justice White noted that even a person adversely affected by discrimination "is not automatically entitled to have a non-minority employee laid off to make room for him." Firefighters Local Union No. 1784 v. Stotts, 104 S.Ct. 2576, 2588 (1984).

79. United Steelworkers of America v. Weber, 443 U.S. 193, 208 (1979).

80. In at least one case, a court ordered that a white worker whose expectation of a promotion was disappointed by implementation of an affirmative action plan receive compensation for that disappointment. Mc $\lambda$ leer v. AT\&T, 416 F. Supp. 435 (D.D.C. 1976). The remedy is not dissimilar from that provided to a minority or female worker when the position she was discriminatorily denied is occupied. The relief ordered may include "front pay" (i.c., the salary the employee would receive if she were occupying the position) and priority consideration for any future vacancy. See Franks v. Bowman Transportation Co., 424 U.S. 747 (1976). Courts, however, do not have the authority and flexibility available to legislatures in seeking to mitigate harshness. In some states, efforts have been made to avoid lay-offs through various forms of worksharing. Six states have adopted short-time compensation laws in which employees whose hours have been reduced are able to supplement their income through payments from the state unemployment insurance system. See CrTizens Commission on Civil. Righrs, Affirmative Action to Open the Doors of Job Opportunity, 156 (1984). 
the Court time and again has taken the broad formula articulated in Brown II-that "equity has been characterized by a practical flexibility in shaping its remedies and by a facility for adjusting and reconciling public and private needs" ${ }^{\prime \prime}$ - and sought to apply it in affirmative and pragmatic ways.

If the imprecision of the Court's approach offends the purist, it must be weighed against alternative approaches to remedy. The principal alternative was articulated by Justice Rehnquist, writing for the Court in Dayton Board of Education v. Brinkman:

If [school segregation] violations are found, the District Court in the first instance ... must determine how much incremental segregative effect these violations had on the racial distribution of the Dayton school population as presently constituted, when that distribution is compared to what it would have been in the absence of such constitutional violations. The remedy must be designed to redress that difference .... ${ }^{82}$

Justice Rehnquist warns against the dangers of a school desegregation remedy that does too much. His words are echoed by the words and policies of the Reagan Administration, which in education, employment and other contexts would not permit opportunities to be offered to a black person who could not establish that she was a direct victim of discrimination or if it appeared that the remedy might permit her to occupy a position she might not have reached absent discrimination. ${ }^{83}$ Assuming that some segregation would likely exist in public schools even if the government had never decreed it, there is no known method for extracting it from the immeasurable consequences of a public order that separated and stigmatized black people for more than two centuries. Unless such a technique is discovered, Justice Rehnquist's quest for "incremental segregative effect" is an exercise in fiction.

In the film It's a Wonderful Life, the protagonist, played by James Stewart, considers his life a failure and is on the verge of suicide when a guardian angel intervenes. The angel is able to recreate the distressed circumstances of the hero's town, friends and family as they would have been if the hero had never lived and thus demonstrates to him that he had not been a failure but had made a real contribution to the well-being and prosperity of all. The movie ends happily.

81. 349 U.S. at 300 (footnotes omitted).

82. 433 U.S. 406,420 (1977) (Dayton $I$ ) (emphasis added).

83. See, e.g., Hearings on School Desegregation Before the Subcommittee on Civil and Constitutional Rights of the House Committee on the Judiciary, 97th Cong., 1st Sess. 614 (1981) (statement of William B. Reynolds). 
Lacking such divine intervention, judges and lawyers in school segregation cases cannot recreate the situation that would have existed if the wrong had never occurred. The party bearing the legal burden of persuasion would always lose. Because Justice Rehnquist would place that burden on black parents and children by requiring them to prove that segregation would not exist in any event and because there is no way to meet that burden, plaintiffs would rarely, if ever, achieve more than a token remedy.

A majority of the current Court has rejected the Rehnquist view, saying that once deliberate practices of discrimination are proved, it is the defendants' burden to demonstrate that any segregation they propose to allow to remain was innocently caused; ${ }^{84}$ defendants can no more meet this burden than black plaintiffs could meet the Rehnquist burden. Although the majority's use of presumptions may be no less artificial than Rehnquist's, the Court's approach is grounded in an understanding that the risks of doing too little far exceed those of doing too much. If a court does too little-that is, permits the continuation of some segregation that may be attributable to government bias-the harm is irreparable. Some minority children will spend their entire school careers in racially isolated classrooms designed for them by government authorities. Similarly if a black litigant is denied a job opportunity because she cannot establish that she is a direct victim of proven discriminatory practices or because race conscious remedies are deemed excessive, she may never have another such opportunity.

If, on the other hand, a court should err by doing too much, by, for example, ordering more desegregation than is warranted, the harm is far less serious and is of a temporary nature. Although parents who would choose to send their children to racially homogeneous schools will find their freedom constrained in that they will no longer be able to assure that choice by living in a segregated neighborhood, this can hardly be deemed a constraint that does serious injury. It is also a temporary constraint, for the court has made clear that once desegregation plans have been implemented for a period of time, courts will not be responsible for correcting resegregation that occurs unless it is caused by government action. ${ }^{85}$ When the duration of the remedy is thus limited, the harm from doing too much is minimized if not eliminated. For if segregation is the result of private preference, it will reemerge, creating in practice the condition (what "would have been in the absence of . . . constitutional violations") that Justice Rehnquist says he would like to attain.

84. Dayton Bd. of Educ. v. Brinkman, 443 U.S. 526 (1979) (Dayton II); Keyes v. School Dist. No. 1, Denver, Colo., 413 U.S. 189 (1973).

85. Swann, 402 U.S. at 31-32. 
Indeed, the Court's current formulation of remedy may err on the side of doing too little rather than too much. It is reasonable to assume that the continued preferences of many citizens for racial segregation result, in part, from many years of conditioning of attitudes under the governmentimposed regimen of segregation. If the period allowed for active court supervision of the effort to accomplish the affirmative duty to desegregate and to eliminate official discrimination is a short one (and many courts interpret Swann as permitting three to five years for "racial balancing") it is questionable whether there is sufficient time to counteract the effects of years of state-imposed segregation. ${ }^{86}$

Race conscious employment remedies, like affirmative school desegregation plans, are justified by courts as temporary expedients that will lapse once the original wrong has been corrected. Critics of such remedies have expressed fears that, whatever the original intention, preferences are likely to become ingrained. Moreover, they note that the time span of the remedy in some decisions may be as long as it takes for the minority workforce of a defendant to reflect that of the relevant labor market. ${ }^{87}$ But under the most stringent of such remedy orders, employers have available to them the defense that good faith efforts did not produce minority applicants who met the employer's legitimate needs. Ordinarily, the greatest movement to train and hire employees occurs in the years immediately following a court order or consent decree. If progress does not occur then, it seems hardly likely that the passage of time will produce more rigorous enforcement. To the contrary, as the remedies sought become more remote in time from the blatant wrongs that originally gave rise to them, the zeal for enforcement may naturally, if unfortunately, be expected to fade.

In sum, there is abundant evidence that affirmative remedies, notably those that have broken old patterns of racial isolation and provided tangible opportunities for education and employment, have been the principal legal engine of black progress. The attack that has been mounted on the

86. The dangers are well illustrated by the recent decision of the Fourth Circuit in Riddick v. School Bd. of the City of Norfolk, No. 84-1815 (4th Cir., Jan. 8, 1985). Contra Dowell v. Board of Educ. of Oklahoma City Pub. Schools, No. 85-1086 (10th Cir. June 26, 1986). In the Riddick case, the district court, having ceased active supervision of a 1971 plan in 1976 and declared the Norfolk district "unitary," permitted the district in 1985 to substitute a "neighborhood school plan" for elementary schools with the knowledge that ten schools would become virtually all black. Although segregated public housing projects continued to exist and the "neighborhood" plan might well have been regarded as a new intentional act of racial segregation, the district and circuit courts accepted the board's justifications that the plan was needed to stem white flight and the loss of parental participation in school affairs. Thus, racial attitudes engendered in part by government-imposed segregation were used to justify a return to segregation.

87. In Weber, Justice Brennan described the agreement between the Kaiser company and the union as designed not to maintain racial balance but to eliminate a manifest imbalance, noting that preferential selection of black trainees would end as soon as the craft workers in the Gramercy Plant approximate the percentage of blacks in the local labor force. United Steelworkers of America v. Weber, 442 U.S. 193, 208-09 (1979). 
legal basis for affirmative remedy rests on a failure (or refusal) to understand the pervasive effects of the caste system and the need for practical, direct, remedial measures to prevent these effects from continuing long after the termination of formal policies of exclusion and discrimination.

After two decades of experience, however, the limitations of race conscious civil rights remedies standing alone as a means for advancement for low-income black people are as apparent as the positive results such remedies have achieved. One may forcefully argue that the depressed economic status and earning abilities of many blacks result from the old order of racism and the failure of government to intervene in any meaningful way to provide opportunities. With the passage of time, however, such arguments, though valid, are less likely to persuade. And if legislative support for programs such as child care, job training, health and nutrition assistance diminishes, affirmative action remedies will lack the base for effectiveness. The issue then becomes whether equal protection doctrine has anything meaningful to say about the current conditions of poor black people and whether the courts have any significant role to play in ameliorating those conditions.

\section{The Courts and the Isolation of the Poor}

In his 1960 defense of the Brown decision, Charles Black put the issue as follows:

. . [I]f a whole race of people finds itself confined within a system which is set up and continued for the very purpose of keeping it in an inferior station, and if the question is then solemnly propounded whether such a race is being treated 'equally,' I think we ought to exercise one of the sovereign prerogatives of philosophers-that of laughter. ${ }^{88}$

In the 1980's, in large part because of the success in implementing Brown, the question requires reformulation. No longer can it be said that a "whole race" is being kept in an inferior status. Once the shackles of the caste system were removed, many black people by dint of their own efforts struggled and attained equal status, albeit a status tinged with periodic unpleasant reminders from bigoted whites of the old order of discrimination. At the same time, other members of the race are confined within a system that keeps them in an inferior status and makes it extremely difficult to acquire the skills and the tools necessary to effect an escape. Government policies offer little or no help to people in acquiring such skills,

88. Black, supra note 4 , at 421 . 
and government practices keep the poor geographically isolated from the rest of society, cut off from services and contacts that might assist their mobility. Because of our failure to eliminate the continuing effects of the old racial caste system, black people form a disproportionately large part of this class of poor. Yet their current circumstances do not differ materially from whites who are also locked in poverty.

It is this changed environment that has spurred increasing academic discussion of the "declining significance of race"-the basic proposition being that the plight of the black underclass is now determined largely by socioeconomic factors such as a lack of education and skills, rather than racial factors such as continued discrimination. ${ }^{89}$ For conservative proponents of the thesis, the prescription is a kind of "benign neglect"-opposition to race conscious civil rights remedies and a belief that government should get out of the social reform business and rely upon the market place.

For more radical adherents of the "class not race" thesis, the moral is that government should attack the causes of poverty and deprivation on a far broader scale than is reflected in the piecemeal civil rights and social welfare efforts of the past and present. Many would argue for the establishment of a series of entitlements in the areas of jobs, housing, education and welfare and for revisions in economic and tax policy designed to redistribute wealth to lower income people.

The merits and the politics of these views and proposals will not be discussed here, other than to note that conservative proponents of "class not race" seem remarkably oblivious to the continuing effects of the racial caste system on the economic and social status of black people, while more radical adherents of the thesis tend to underrate both the progress made under civil rights laws and the unique institutional commitment the Supreme Court has revealed when dealing with racial as distinguished from other forms of discrimination. Rather, the question to be examined in this concluding section is what role, if any, the judiciary may appropriately play in reform efforts designed to deal with the debilitating effects of distinctions based on wealth or class rather than race.

A review of the history of wealth discrimination cases suggests a pessimistic prognosis for litigation that seeks benefit entitlements based on constitutional rather than statutory arguments or that calls for significant redistributions of public resources. In contrast, the institutional concerns of the judiciary that have inhibited relief in those types of cases may not be a bar to suits challenging government practices that isolate poor people and

89. See, e.g., Wilson, supra note 11. 
deny them access to services and jobs that may be critical to their advancement.

\section{A. Pathways and Barriers to Judicial Relief for the Poor}

The effort to use the courts to protect the interests of the poor gained vitality in 1941 when the Supreme Court invalidated a California law prohibiting the entry of non-resident indigents into the state. Justice Jackson, in a concurring opinion, wrote,

[A] man's mere property status, without more, cannot be used by a state to test, qualify, or limit his rights as a citizen of the United States. . . The mere state of being without funds is a neutral fact-constitutionally an irrelevance, like race, creed or color. ${ }^{90}$

From that point on, through the 1960's, the Supreme Court struck down a series of state-imposed constraints on the right to vote, ${ }^{91}$ to obtain legal assistance when charged with a crime, ${ }^{92}$ and to receive welfare benefits without having to meet state residency requirements. ${ }^{93}$ Almost all of the cases, however, involved practices that impeded access of poor people to the political or judicial processes, such as the requirement that citizens pay poll taxes in order to vote or that defendants in criminal cases pay the costs of their own transcripts in order to appeal. In most of these cases, the costs of providing access to the poor were relatively minimal.

Once the courts faced claims that potentially involved much larger redistributions of resources, the decisions began to go the other way. The problem that faced the courts is well illustrated by the Rodriguez decision in 1974 in which the Supreme Court by a five-to-four margin rejected a Fourteenth Amendment claim challenging inequities in the financing of public schools. ${ }^{94}$ The claimants argued that strict scrutiny should be applied to school financing because public education was a "fundamental right" and because most of those who suffered inequity under the Texas finance plan were low-income people. But the majority was clearly troubled by the lack of limiting principles in the plaintiffs' claim. The class of people disadvantaged in the view of the majority was not well-defined by

90. Edwards v. California, 314 U.S. 160, 184-85 (1941).

91. See, e.g., Harper v. Virginia Bd. of Elections, 383 U.S. 663 (1966).

92. See, e.g., Griffin v. Illinois, 351 U.S. 12 (1956).

93. Shapiro v. Thompson, 394 U.S. 618 (1969). In Shapiro, state requirements conditioning the receipt of welfare assistance on meeting one year residency rules were invalidated on equal protection grounds. In Edwards, the Justices, though concerned with similar impediments on the right to travel, had rested their decision variously on the commerce and privileges and immunities clauses. 314 U.S. 160.

94. San Antonio Indep. School Dist. v. Rodriguez, 411 U.S. 1 (1973). 
income. ${ }^{95}$ And if public education were deemed a fundamental right, could not similar claims be made about such matters as police and fire protection, nutrition, and housing?

Similarly, if courts were to venture beyond voting and the criminal defense system to mandate the provision of free services to people without means, where would they draw the line? If the courts were to read the equal protection clause as mandating an "affirmative duty to lift the handicaps flowing from differences in economic circumstances," ${ }^{\text {"98 }}$ they might find themselves issuing remedies calling for the redistribution of resources in such areas as housing, education, health and municipal services. Judges would be subjected to charges that they had usurped legislative prerogatives by redistributing resources that elected bodies had already decided to distribute in a different way.

Nor is it merely abstract notions of judicial restraint that feed such concerns. The reality is that the legislative branch controls the national purse strings and the executive branch possesses the police authority to enforce the laws. Gourts must rely on the cooperation of these other branches, as well as on public acceptance of the legitimacy of their decisions, if those decisions are to be accepted and enforced. A series of decisions calling for large-scale redistribution of resources, however strongly based on considerations of fundamental fairness, could bring on the kind of confrontation that the judiciary normally seeks to avoid.

This does not mean that the courts will or ought to avoid entirely those remedies that place claims on the public fisc. Lower courts have ordered states to appropriate substantial sums of money to make prison systems minimally habitable and to provide minimum levels of care and treatment at state mental health facilities. ${ }^{97}$ The Supreme Court, as we have seen, has mandated the expenditure of substantial sums for compensatory education to redress the wrongs done by racial segregation ${ }^{98}$ and has required that states make money available for the free public education of children of undocumented aliens. ${ }^{99}$ In almost all of these cases, however, the court has been able to discern some limiting principle (e.g., the "absolute" rather than the relative deprivation of a public service in Plyler) that would prevent the decision from being extended widely to the other areas.

Absent such special circumstances, the courts have sent a clear message, particularly over the past decade, that they will not serve as major vehicles

\footnotetext{
95. Id. at 28.

96. This was the characterization used by Justice Harlan in dissent in Griffin v. Illinois, 351 U.S. 12,34 (1956).

97. See, e.g., Hoptowit v. Ray, 682 F.2d 1237 (9th Cir. 1982); Donaldson v. O'Connor, 493 F.2d 507 (5th Cir. 1974), vacated and remanded, 422 U.S. 563 (1975).

98. See Milliken II, 433 U.S. 267.

99. Plyler v. Doe, 457 U.S. 202 (1982).
} 
for redressing economic injustices visited on the poor. ${ }^{100}$ They have rejected such claims even in circumstances where it was demonstrated that the economic distinction had particularly harsh consequences for black citizens. $^{101}$

\section{B. The Isolation of the Poor}

If claims to benefit entitlements have fared badly in the courts, do poor people have grievances that are more amenable to judicial redress? In 1986 , it seems clear that the practice at all levels of government is to physically isolate poor people. National housing policy aims to achieve the lofty goal of "a decent home and a suitable living environment" for all American citizens. ${ }^{102}$ But housing officials throughout the country routinely locate housing for low-income people in the poorest neighborhoods of a community where their neighbors will be other low-income people, usually of the same race. ${ }^{103}$ Moreover, the officials of affluent jurisdictions have managed to exclude the poor entirely from their communities through the manipulation of zoning and land use controls that bar the construction of housing affordable by low-income families.

This physical isolation denies poor people access to job opportunities in burgeoning suburban areas and to superior public services including public schools. Political boundary lines have been treated by the Supreme Court as at least partial barriers to the racial (and thus economic) integration of public schools. ${ }^{104}$ And even where some racial and economic mix exists in the schools, rigid tracking practices begun in the early grades often assure that lower-income children are isolated in classrooms and programmed for low-status occupations. ${ }^{105}$

Evidence of the harm that inheres in such isolation has been discussed throughout this essay and clearly applies in many cases to class as well as to racial segregation. Indeed, Justice Burger specifically noted in Milliken

100. See, e.g., Ross v. Moffitt, 417 U.S. 600 (1974) (state not constitutionally required to appoint counsel for indigent state prisoners seeking discretionary review); Dandridge v. Williams, 397 U.S. 471 (1970) (upholding state's maximum grant provisions in AFDC programs under which large families received less than computed need); Jefferson v. Hackney, 406 U.S. 535 (1972) (upholding Texas scheme of allotting lower percentage of calculated need to AFDC families than to recipients of other types of aid).

101. Jefferson, 406 U.S. at 547.

102. Housing $\Lambda$ ct of 1949, P.L. No. 81-171, 63 Stat. 413 (1949).

103. See, e.g., Citizens' Commission on Civil Rights, A Decent Home (1983) (federal housing policies segregate the poor).

104. See Milliken I, 418 U.S. 717 (1974). The 5-4 majority ruled that inter-district desegregation was permissible only when, through boundary manipulation or other actions, government officials had caused segregation that had effects across district lines.

105. See, e.g., Hobson v. Hansen, 269 F. Supp. 401 (D.D.C. 1967), cert. dismissed, 393 U.S. 801 (1968). Judge J. Skelly Wright, who wrote the opinion, is one of the very few jurists who have discussed the impact of segregative practices in terms of class as well as race. 
II that the damage done to children who are "educationally and culturally set apart from the larger community" is "not peculiar to race [and] can affect any children who, as a group, are isolated by force of law from the mainstream." 108 The opportunities made available through ending government-enforced isolation have also become clear in the thirty-plus years since Brown. ${ }^{107}$

A potential judicial remedy for the consequences of isolation by class status is suggested by an analysis begun but not completed in the Rodriguez case. The Court accepted the time-honored concept of community control as justification for permitting educational expenditures to be determined by the property wealth of each community, even though this method resulted in massive disparities. ${ }^{108}$ According to this view, each community should be free to decide for itself how much it should be taxed for local services and how the taxes should be allocated for various purposes. The plaintiffs objected that local control was illusory because in a property-poor community citizens could decide that they valued public education highly and were willing to tax themselves heavily and still produce much less revenue for public schools than a property-rich community could with much less tax effort.

"Well," the Rodriguez majority might have replied, "citizens who value public education highly are free to vote with their feet-to relocate to communities where public schools are well financed and taxes are low." The response, of course, is that while this option may be available to some, it is foreclosed to poor people who are barred by zoning, land use controls, or other measures from securing residences in communities that provide the services they desire.

Thus, the class of people most directly harmed by inequitable state financing schemes is anything but amorphous. It consists of poor people, including and especially the black poor, who have no freedom of movement. If the Court's belief, implicit or explicit, is that reform of state financing systems that result in grossly disparate public services is too legislative or political a task to be undertaken by the judiciary, then a measure of equal protection may be achieved by removing impediments that poor

106. Milliken II, 433 U.S. at 287 (citation omitted).

107. In Hills v. Gautreaux, the Supreme Court upheld lower court orders requiring the United States to help make housing available to low-income black citizens outside the central city as a remedy for segregative practices. 425 U.S. 284 (1976). Positive results stemming from the decision are reported in U.S. DEP'T of Housing and URBan Development, Gautreaux Housing DemonStration: An Evaluation of Its Impact on Participating Households (1979). A mote recent study, showing beneficial school results for low-income black children, is summarized in URBAN Affairs Nkws 1 (Center for Urban Affairs and Policy Research, Northwestern University, Fall 1985). Evidence on the beneficial effects of school desegregation is summarized supra notes $36-41$ and accompanying text.

108. Rodriguez, 411 U.S. at 49-50. 
people face in gaining access to better services. Such an approach would be consonant with the recognition of a basic right to freedom of movement in the Edwards and Shapiro cases ${ }^{108}$ and with the recognition as early as Edwards that "the task of providing assistance to the needy has ceased to be local in character."110

Of course, judicial redress limited to removing discriminatory site selection practices or land use controls may turn out to be ineffective relief for the poor. Its efficacy depends on the existence of government subsidy programs to bring standard housing within the reach of low-income people. Without such affirmative assistance, the removal of negative impediments will not result in tangible changes in the lives of poor people. Over the last several years, federal housing assistance to low-income people has been on the wane, and even in its peak years, it did not come close to meeting the need. Thus, legislative inaction could largely negate the potential gains of judicial relief.

The same observation, however, is applicable to the Brown decision. It is clear, at least in retrospect, that Brown's success depended on the willingness of the legislative and executive branches to furnish affirmative support. The Court became the catalyst that impelled the nation to confront problems most people preferred to ignore. By confronting government policies and practices of isolating the poor, the Court could serve a similar role.

\section{How Much Judicial Scrutiny for Poor People?}

As in many cases of constitutional adjudication, the outcome of challenges to government practices of isolating the poor is likely to turn on the level of scrutiny the Court is willing to apply them. If all that is required is a rational basis for practices that deprive the poor of access to services and opportunities, justification will ordinarily be found. For example, land use practices that exclude housing for low-income people may be rationalized as serving a variety of economic and environmental purposes.

The basis for invoking a stricter standard of review is found in the celebrated footnote four of the Carolene Products decision:

109. Edwards, 314 U. S. 160; Shapiro, 394 U.S. 618. It would not be consonant, however, with the Court's decision in James v. Valtierra, 402 U.S. 137 (1971). There the Court upheld an amendment to the California Constitution allowing the development of low-rent housing in a community to be vetoed by a local referendum.

110. Fdwards, 314 U.S. at 174-75. A contemporary statement of the obligation of communities to share the responsibility for meeting the housing needs of the poor is found in South Burlington NA $\Lambda$ CP v. Township of Mt. Laurel, 67 N.J. 151, 336 A.2d 713, cert. denied E appeal dismissed, 423 U.S. 808 (1975). In Mt. Laurel, the New Jersey Supreme Court found in the state equal protection clause a basis for requiring jurisdictions to meet this shared responsibility. 
[P]rejudice against discrete and insular minorities may be a special condition which tends seriously to curtail the operation of those political processes ordinarily to be relied upon to protect minorities and which may call for a correspondingly more searching judicial inquiry. ${ }^{111}$

If Carolene Products continues to provide even a rough guide to those circumstances in which courts ought to be ready to intervene to curb majoritarian excesses against disfavored groups, then "searching judicial inquiry" should be invoked with respect to government practices that work to the disadvantage of poor people. ${ }^{112}$

In one sense, the poor may not be "discrete," in that each year some leave and others join the ranks of those with incomes below the subsistence level. ${ }^{113}$ By contrast, blacks and members of other racial minorities which were disfavored under the racial caste system were more discrete, for they were generally identifiable and few could escape the identification even if they preferred to do so. Ironically, this physical attribute that made them easy targets for discrimination as discrete groups ultimately helped them to fight for equality. Thus, out of the adversity of the caste system, blacks forged a sense of solidarity and tools of political organization that ultimately led to a degree of success in the political process. That solidarity and political organization are almost entirely lacking among the poor; indeed, the shifting membership of the poor reinforces a need for special protection.

Other factors have progressively weakened the efficacy of low-income people in the political process and are likely to leave them in an even more precarious condition in the future. At one time, unskilled people, immigrants and others, were needed to build the nation's industrial capacity. During the Depression, the ranks of the poor were so large that the government's failure to redress their grievances would have threatened the political as well as the economic stability of the country. The success since World War II in reducing the number of poor people through economic growth, social legislation addressing the needs of older people, and the impact of the civil rights revolution, has substantially diminished the potential force of any political movement on behalf of the poor. Perhaps more important, the needs of the economic system have shifted dramati-

111. United States v. Carolene Prods., 304 U.S. 144, 152 n.4 (1938).

112. There has been spirited academic debate over whether the Carolene principle is over- or under-inclusive or should be revised to better state the basis for heightened scrutiny. See, e.g., ELY, Democracy and Distrust (1980); Ackerman, Beyond Carolene Products, 98 Harv. L. Rev. 713 (1985). Almost all commentators agree, however, that there should be some special judicial protection for those worst-off in our society.

113. See supra note 32 . 
cally. Manufacturing has become less central to the American economy, and with increased reliance on other nations as sources of supply for cheap labor, unskilled American workers have become economically disposable people.

One other important change is the crucial role of financial contributions in shaping the results of elections and the outcomes of political issues. Since the defining characteristic of the poor is lack of money, it must be acknowledged that they are at a greater disadvantage than ever before in relying on the political processes for basic protections.

Nor is the character of prejudice against the poor such that the disabilities listed above are likely to be compensated for in other ways. Racism in the various forms it has taken since the importation of the first slave is undoubtedly the most malevolent and deeply ingrained "prejudice" that has affected the American polity. But for that very reason, and because it so patently contradicted the general professions of equality found in our charter documents, the issue of race has remained highly visible over the course of two centuries. Moreover, it could hardly be denied that the government played an integral role in the system of oppression that relegated blacks, Hispanics, Asians and Native Americans to the status of secondclass citizens. That fact, too, ultimately became a persuasive argument for the responsibility of government to take corrective action. By contrast, although the facts may be more complicated, the general view of the government's role in contributing to the plight of poor people is that it has at most been one of neglect rather than active participation.

Support for civil rights legislation also was bolstered by an ultimate recognition that race is an immutable characteristic and that it is fundamentally unfair to permit a person to be penalized for a condition she is helpless to change. By contrast, the general public view is that the poor in most circumstances are responsible for their own condition and, therefore, that government's obligation to assist them is very limited. ${ }^{114}$

All of this is not to say that ultimately altruistic sentiments and a belief in fairness on the part of most Americans may not lead to more equitable treatment of poor people. Indeed, unless such a change occurs and is reflected in legislative policy, little progress can be expected. It does suggest, however, that as long as the courts have a role in assuring basic protection

114. Obviously, public attitudes may vary, depending on the perceived causes and whether the poor are regarded as "deserving" or "undeserving." Those threatened with impoverishment because they are old have received a more positive response from government than others in part because age, like race, is understood as an immutable characteristic (and also because their growing numbers have made them a strong political force). Children might ordinarily be thought to be among the "deserving poor" since they certainly cannot be held responsible for their own plight. But in their treatment under welfare programs, they appear to be held hostage to a belief that payments adequate to meet their needs would encourage welfare dependence by their mothers. 
for those who have the odds stacked heavily against them in the political system, poor people have a powerful claim for such protection. This conclusion may apply with particular force when dealing with practices that isolate the poor. Experience has shown that the separation of blacks from whites provided fertile ground for the growth of stereotypes, fears and mistrust between the races and that only when the wall of isolation began to crack did the attitudinal barriers to black progress begin to lower. Similarly, the political processes "ordinarily to be relied on" may function in a more informed and positive fashion once barriers to understanding created by isolation of the poor are lowered.

\section{Conclusion}

If the books were to be closed on Brown v. Board of Education today, the decision would have to be deemed a resounding success. What happened in the aftermath of the decision demonstrated how deeply entrenched and difficult to dislodge our racial caste system had been. But it also demonstrated that law-including the law declared by federal courts in interpreting the Constitution-can serve as a means of empowering the powerless, enabling them to make changes in their own lives which permit them to develop their potential and participate more fully in the society in which they live.

Brown has also validated the role of the judiciary as a catalyst in helping to renew and revitalize our political processes. Apart from the success achieved in its own sphere, the movement for black civil rights has played an important role in spawning similar legal and political movements that have asserted the rights of women, Hispanic Americans, the disabled, the elderly, and other minority groups. Most of us have become more aware of the unjust limitations that government and society have imposed on minority citizens, women, the disabled and others and how our own prejudices and stereotypes have contributed to these barriers. Once aroused, this consciousness of injustice does not fade easily, even under the prod of regressive leadership. Thus, the progress that has been made is not likely to evaporate.

But the gains of the past three decades have occurred against the backdrop of a society growing increasingly stratified by class and income status. For many, the "escape" routes to middle-class status have become far more difficult to negotiate. Black people, not surprisingly, constitute a disproportionately large segment of those who have become most deeply mired in poverty.

In the approach that they have taken to civil rights remedies, the courts have been able to ameliorate the problem to some degree. They have approached the issues with an understanding that the caste system has had 
severe and continuing impact on the lives of blacks, consequences that are real and that persist even though they resist precise measurement. Largely eschewing theoretical debates about "color blindness," the courts have sought in most cases to provide practical opportunities to black people, bounded only by the need to recognize the legitimate interests of others.

However, practices and policies that isolate the poor and deny them access to resources and services needed to change their condition go far beyond the current reach of civil rights remedies. In approaching problems of class and wealth discrimination, the courts are faced with institutional limitations and problems even thornier than those they confronted in dealing with race. But that does not mean that the judiciary is without authority and responsibility. The judiciary remains the monitor of the integrity of the political process, the agency for compelling the other branches of government and the people to face up to issues we prefer to ignore.

The response of the nation to problems of continuing discrimination and deprivation no doubt will emerge from the warring instincts of hope and fear, of generosity and meanness, that reside within each of us, and the quality of the political leadership that appeals to those instincts. The role of the judiciary is limited but crucial; if it performs its function, it may help our better natures to prevail. 
